\title{
Partnership-based business modelling as an opportunity in the context of globalisation and as a challenge for business models
}

\author{
Andris Vanags ${ }^{1, *}$, Zane Drinke $^{1}$ \\ ${ }^{1}$ Turība University, Faculty of Business Administration, Department of Commerce, 68 Graudu Street, \\ Riga, Latvia
}

\begin{abstract}
.
Research background: Management of the complex reality transformation to the world of the future- is often associated with discovering new directions in a company's activities. One of these directions is the formation of beneficial partnerships aimed at working together to achieve certain goals, which in turn relate to necessary changes within the company. Change has become inevitable in every enterprise and phased management of change is becoming a daily component of administration and a part of company's development: the speed, scale and complexity of change is increasing nowadays, and it is impossible to stop this flow. In this context it is very important to determine to what extent and in what aspects a company needs change.

Purpose of the article: The aim of the research is to investigate what factors could influence and what aspects could be affected by reinventing the existing business model and establishing a new partnership-based business model within a company and what should be done to implement this change successfully.

Research methods: literature analysis, semi-structured interviews and a survey. The research data was processed by continuous comparative analysis, using open coding, level 2 coding, content analysis method. Findings \& Value added: the results drawn from this study could provide academics and practitioners with a better understanding of communication and change-readiness capabilities. This knowledge can then be applied to their strategies and management skills for the purpose of achieving partnership-based business model with success.
\end{abstract}

Keywords: change management; business models; partnership-based business model

JEL Classification: L26; D22; F61; L14; L21; L22

${ }^{*}$ Corresponding author: andris.vanags@sakret.lv 


\section{Introduction}

Business environment has become more complex, external environment has become global: foreign markets - more accessible, and national borders are no longer an obstacle to reducing their impact. Economic paradigms have become chaotically dynamic and at the same time predictable in different directions. Change has become inevitable in every company and change management is becoming an everyday component of management and an integral part of company development: speed, scale and complexity of change are increasing and it is impossible to stop this flow. Therefore, it is very important to determine which aspects change is needed and what factors influence the company's work, so that the change implementation can be promoted without threatening the company's existence.

Sustainability and competitiveness of the company's operations are based on resources that are closely related to knowledge and its transformation into competencies that can be only realized using the structure of physical and social resources. In order to increase the competitiveness of a company and make it possible to manage it, it is necessary to acquire new knowledge and experience, new practices and theories, which, like business environment, have become more complex and diverse. Business modelling helps a company make the transition from today's world to the world of the future and implement transformation. It has become very popular as change has become much more frequent. The company has to manage several changes at the same time, and at different stages of their development. With the help of business modelling, it is possible to manage the reality of complex changes. It is related to the discovery of new directions in the company's operations. One of these directions is the creation of beneficial partnerships aimed at working together to achieve certain goals. Partnership affects company's operating potential and expands opportunities in its external environment; at the same time, it promotes change in the internal environment. Changes in the external environment, which affect the company's internal environment and promote new changes in it, must be managed so that the process of change does not interrupt the business, but provides new benefits to the company. Business management is also experiencing a revolution in the form of active participation of all employees in the company's work processes and formation of attitudes towards change.

The aim of the research is to investigate what factors influence and what aspects affect the existing business model and what should be done to implement change successfully.

\section{Methods}

The theoretical part consists of the scientific literature analysis. Semi-structured interviews with 3 experts working in the Latvian construction industry. The aim of interviews was to assess the aspects of cooperation as well as change management, that are relevant from the manager's point of view in the context of change and influence the process of change itself. The choice of the experts was based on the diversity of their expertise in several construction business areas: among the experts were the Chairman of the Board of the Trading House "Kurši" - A.B. (interview on 23 May 2020), the Chairman of the Board of Optimera Latvija SIA - A.K. (interview on 18 May 2020) and SIA „Cemex” commercial director M.G. (interview on 16 June 2020). The research data was processed by continuous comparative analysis, using open coding, level 2 coding, axial coding and content analysis method with inductive and deductive approach [1]. In addition to expert interviews, a survey of employees and managers of SIA Sakret was conducted. A total of 16 managers (94\% of all) and 70 employees (61\% of all) in Latvia, Lithuania and Estonia were surveyed. Survey respondents ranked the impact factors according to their importance and rated them by using the Likert scale with points, where is1(irrelevant); 2(unimportant); 3(moderate); 4(important); 5(very 
important), the degree of significance was determined for each factor. The data are presented in the form of diagrams and tables.

\section{Results}

Strategic partnerships are gaining ground in the business environment at high speeds. Companies can work with partners from different countries and industries, exploiting risk reduction potential and sharing resources, benefiting from technological convergence and industrial deconstruction. A partnership-based business model facilitates this process, while reducing costs and increasing the company's competitiveness. Many entrepreneurial firms rely on a single distribution channel, but those that were able to shift channels, especially during the COVID-19 pandemic... had an edge on others that could not. The pandemic force large and small firms alike to rely more heavily on online distribution" [2]. In order to make changes in the current business model in the direction of multi-channel strategy, it is necessary to understand whether the company is prepared for these changes, what needs to be changed in the existing business model and what factors influence the change process. It has been argued that a threshold level of maturity is needed in order for organizations to engage successfully in participatory approaches to change [3].

Strategic partnership is an agreement between two or more companies in which internal and external partnerships are "vital to the organization and its specific opportunities and threats" [6]. On the one hand, partnerships are characterized by "mutual trust and commitment, willingness to openly acknowledge problems, share data and ideas, improvements and best practices, the desire to continually improve products and services" [7]. On the other hand, starting a new partnership does not always guarantee success and an immediate realization of the above-mentioned benefits: due to the stated lack of mutual coordination and uncertainty of cooperation, the formation of a strategic partnership in the initial stage can negatively affect the company's work [8].

Modern management approaches are also very different from the traditional approach to management processes: unconditional, pragmatic and only analytically based management of a company could jeopardize the sustainability of the company's operations [9]. This indicates the emergence of a new alternative management approach. The new approach includes the involvement of company employees in the planning, strategy and change processes. When employees are committed to the strategy, "...they recognize that their efforts are an integral part of the organization's successful strategy implementation" [10]. It is the provision of information about the ongoing changes in the external environment as well as their impact on the company's internal environment; it is an opportunity to evaluate good and bad experience [11]. The need for change management should be planned and prepared together with the introduction of a new partnership-based model. In order to realize the transition, the company's tendency to change must be detectable: competitiveness and advantages in the operating markets as well as the quality of the implementation's result. Highly motivated and professional employees are an important condition for successful operation of the company: "...employee work engagement is crucial" [12], because the relationship significantly affect partnerships.

Any change triggers a reaction, which in turn triggers a new action: change is the starting point of a future chain of events and requires mechanisms and approaches to manage adverse reactions at intermediate stages in the chain [13]; [14]; [15]. In addition to the systematically planned changes, unexpected and unforeseen problems can arise [16]. Managing these changes requires a leader's competence, skill and sense of responsibility. It is clear from experience that the process of change is always diverse and multifaceted, and more or less it affects and interconnects all the company's subsystems [17]. 
Stable organizations maintain their core organizational attributes, such as function and identity, amid dynamic environmental changes; flexible organizations innovate and adapt to these changes. [18] Often, a company's failure is related to management's lack of knowledge about management issues, misunderstanding of change, and management's reluctance to take responsibility and commitment to customers and employees [19]. The chosen time, the speed of project implementation, the company's management's ability to effectively analyse and summarize the available information as well as the ability to evaluate own knowledge is necessary [20].

\subsection{Characteristics of construction companies}

The competitive environment of the Latvian building materials industry is influenced by various factors: there is fierce competition, consumers can choose the services provided by several companies, the offers differ according to the assortment of goods / services, quality and price levels. Most of the Latvian construction industry serves the local market, thus it is closely interconnected with total investments in the national economy. SIA Sakret (founded in 2004) is one of the leading and most modern manufacturers and suppliers of ready-to-use building mixes in the Baltic Sea region, which provides the widest range of construction materials. This study described the operation of JSC Sakret only in the Baltic States.

\subsection{Partnership impact assessment}

By assessing how Partnership-based business models affect the company, authors have identified four important aspects: management view, customer attitude, partner relationship quality and internal organisational changes.

\subsubsection{Management view}

Experts point out that the management strategy of construction companies is a factor that "significantly affects the competitiveness " (A.B.). The table summarizes the main corporate governance criteria which contribute to the successful operation of a company (see Table 1).

Table 1. Characteristics of Management in construction companies

\begin{tabular}{|l|l|l|}
\hline $\begin{array}{l}\text { Providing information } \\
\text { exchange in the company }\end{array}$ & $\begin{array}{l}\text { Structure, Planning, definition } \\
\text { of goals }\end{array}$ & $\begin{array}{l}\text { Profitability measurements for } \\
\text { each management decision }\end{array}$ \\
\hline $\begin{array}{l}\text { Building successful } \\
\text { cooperation in the long run }\end{array}$ & $\begin{array}{l}\text { Management of construction } \\
\text { companies }\end{array}$ & $\begin{array}{l}\text { Fast and operative control } \\
\text { response }\end{array}$ \\
\hline $\begin{array}{l}\text { Employee involvement and } \\
\text { idea generation }\end{array}$ & $\begin{array}{l}\text { Evaluation and improvement } \\
\text { of results }\end{array}$ & Strategy and definition process \\
\hline
\end{tabular}

Experts acknowledge that companies "seek to specialize and develop specific products in order to increase their competitiveness, including in foreign markets" (A.K.). "We adapt to what the market demands" (A.B.). Respondents indicate that creating new products is "expensive and risky" (A.K.). As a result, the interviews highlighted opportunities that the company can use to boost its competitiveness and offer innovations to the market, despite the obstacles of market conditions: "the right management strategy, ...in which partnership is one of the key points" (A.B.). In addition, experts noted that "the strategy does not work well without preparing employees for change" (A.B.) since ultimately individual readiness for change is crucial. Involvement of employees in change processes was also recognized among experts as an important factor in making changes in the company. It is also important to "explain the urgency of this change and why it is important" (A.B.). 


\subsubsection{Change of customer attitude}

Companies improve the quality of both services - production and delivery - by simplifying processes, evaluating and eliminating redundant steps in their business environment. The customers, in turn, obtaining this "fast service" (A.K.) can profit from prompt decision making. As a result, the whole structure of the company is affected and becomes "transparent and controllable" (A.B.) to draw its conclusions timely and to take decisions rightly. Improving processes may mean changing the way in which projects are managed - for example, "the introduction of partnering" (A.K.) - and therefore the client will play a key role in the decision to innovate.

Authors have acknowledged that construction companies also have clients who are “...selective. Products must be constantly replenished, changed...” (A.K.) It is necessary to produce what attracts the customer and what the customer wants. Only then will the customer "recommend you to others and this way he has already advertised for you" (A.B.). This approach to the various aspects of company`s activities - customer service, orderliness of processes, information volume, etc. - has allowed to make some notable changes by offering different and diversified approaches based on client needs and by "improving processes and assigning them" (A.K.) a different kind of speed and quality. The experts think in terms of the customer's perceived benefits from services that construction companies provide. The most important aspect that companies gain from their relationship with customers is their loyal attitude towards these companies and their added value. Another study would be useful to find out the customer's own thoughts on the services provided by construction companies. A comparison of these two results would disclose an objective view of the customer's benefits and benefits through services.

\subsubsection{Changes in partnership relations}

Partnership-based business modelling creates partnerships with which one company completes its range of services and products through the services/products of another company. According to experts, the most important criteria are the partner's influence, communication and honesty. "If you have influence, you also have information" (M.G.). Company has more opportunities to "reach a wider range of consumers, reduce transport costs, production costs, increase production and profit" (A.K.). When partners are involved in the development of services, it is a great opportunity to make the client loyal to companies and create innovative and customer-tailored services. It is an opportunity for a company to "copy successful systems" (A.B.) and "create a huge synergy effect" (A.B.).

According to experts, the criteria of potential cooperation partners are "honesty, reliability, reputation, social responsibility, financial stability, stability of production" (A.B.). In the building materials industry, the potential benefits of cooperation are "personal contacts, knowledge, information and losses - financial resources and independence" (M.G.).

It should be noted that formation of a partnership has different effects. On the one hand, the company is gaining new markets, expanding the range of products, the opportunity to create new innovative products, reduce costs and optimize production and other processes. On the other hand, the creation of new partnerships is a job that has to do with defining the desired and necessary partners, the development of criteria, the arrangement of partner selection and attraction processes. These processes are closely related to the analysis and reinvention of the company's internal environment. As a result of this work, company will change its approaches and methods as well as its attitude towards aspects that have not been analysed yet. The company's ability to respond to changes in the company's internal and external environment impacts company's competitiveness and advantages in the operating 
markets. Both internal and external perceptions of an organization's readiness and willingness are important.

\subsubsection{Internal organizational changes in the company}

When setting up a partnership-based business model, companies must accordingly tailor their entire businesses to it. A new or reinvented business model creates new business strategies in the market, which favour the emergence of advantages over competitors and market the company. By taking a critical analysis of the process quality, their necessity, regularities and relations to other processes as well as evaluating the employee's capability, a construction company can make decisions about selection, qualification and quantity of its employees.

In the course of the research, the authors came to the conclusion that the desire to change and expand with diverse partnerships is not enough. The company's internal environmental infrastructure is much more important, which influences the practical realization of this desire. Experts believe that new ideas and knowledge should be sought primarily "in an internal environment" (A.B.) and only "then in an external environment" (A.B.), working with universities, research centres and scientists in order to generate new ideas and achieve a specific goal. The second part of the research is dedicated to the assessment of company's internal environment. Aspects that were discussed with experts were taken into account in the questions of the questionnaire in order to compare and analyse them from different points of view, as well as to provide a basis for drawing conclusions for companies' management at the end of this research.

The course of the necessary changes in the company is significantly influenced by the preparedness of the company's internal environment for changes. Employees of any company (including managers) are its internal partners, who determine and form the organizational environment, relations with other organizations. Having regard to the fact that change is not an easy concept to be introduced to the employees because people are used to their comfort zone and that any change that demands adjustment is difficult, the authors analyse factors that may influence a new partnership-based model and identify the readiness of the company's internal environment for changes in their research. Assessing employees' readiness serves as a diagnostic tool which assists the organizational leaders in determining where changes are needed in the message or communication strategies [21].

Respondents were asked to rate the factors that significantly affect their work. Evaluating the survey data (using a a scale from 1 (very poor) to 5 (excellent), the authors conclude that the importance of factors for managers and employees is different (see Figure 1).

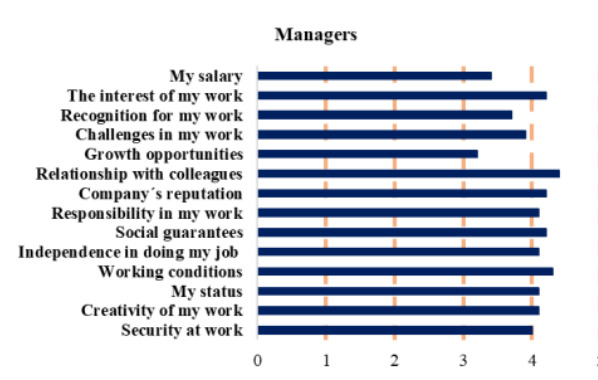

Fig. 1. Factors influencing work

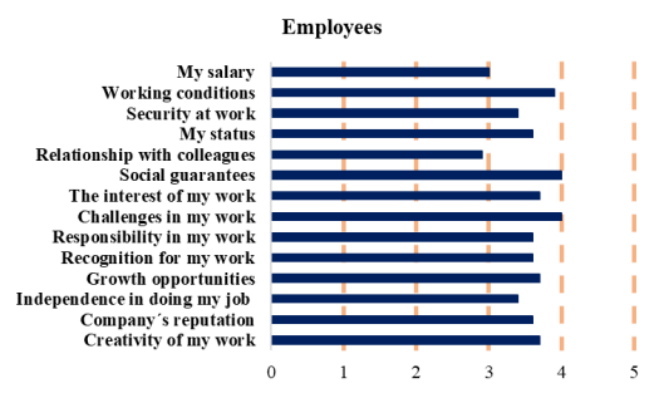

Fig. 2. Range of factors influencing work

The degree of importance determines what factors make employees and managers choose to work in this company. The assessment provided for each factor determines the degree of comfort of the respondents in interaction with these factors. All these aspects form the basis of volume, quality and pace of work of the company's employees. This means that when 
assessing a company's business model and preparing necessary changes, the assessment of key factors will be decisive, which will shape employees' attitudes and attitudes towards change and affect the quality of change.

As shown in Fig. 1, key factors influencing managers' work are mainly related to interest in the job, new challenges, growth opportunities and recognition. These factors are comparable to the preconditions of business modeling that can be expected from the employees involved in business modeling, so it can be concluded that the motivation base among managers is completely appropriate for starting work on a new partnership-based model. Employees have a different assessment and ranking of factors: regardless of remuneration, it is mainly related to working conditions and safety, status and cooperation with other colleagues, although the low assessment of both remuneration and cooperation is noteworthy. This could threaten the success of the change process, taking into account that "cooperation with colleagues is a prerequisite for team cohesion, mutual communication and understanding between colleagues" [22]. Improving the assessment of these factors should be accompanied by changes in the company because people "go where they are wanted and stay where they are appreciated" and their needs are met. Meeting those needs includes "providing satisfying work, making available opportunities, giving positive feedback" (A.K.) and providing a safe, secure work environment.

New challenges at work among employees have been assessed very positively, which indicates that they exist in the company's work. The importance of this factor is low, because employees do not consider it very important in their work. Assuming that in the context of changes, employee initiative and creative approach could be rewarded in addition, it would be possible "to increase both employee satisfaction with remuneration and their identification with the company's overall result, obtaining a completely different assessment factor" [23]. Currently, this factor indicates a weak emotional connection with the company. This is also confirmed by the assessment of the importance of the company's reputation among employees. Considering the fact that employees have a significant impact on how the organization is perceived and help to build and maintain the organization's image, these factors have to be included in change communication, involvement in the processes and motivation to work creatively.

Another important aspect that the authors wanted to explore is the awareness of employees and managers about the company and its strategy, as well as their participation in the development of the company. According to authors, these aspects are decisive when evaluating the existing activities of the company with the aim to prepare for change and create a new business model that meets the company's goals. This information provides the company with information on the quality and intensity of existing communication and on the identification of employees with the company and its goals (see Fig. 3 and 4).

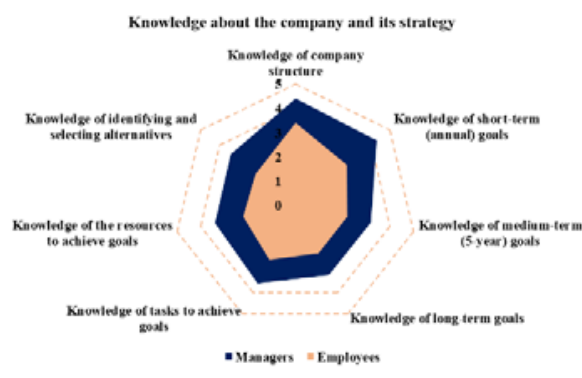

Fig. 3. Knowledge about the company and its strategy

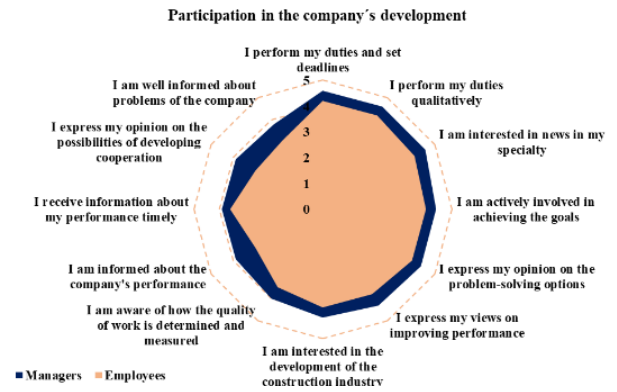

Fig. 4. Participation in the company's development 
The obtained information leads to the conclusion that neither the employees nor the managers gave the highest possible rating to any of the answers. Managers' assessment is mediocre in terms of knowledge of the company, its goals and strategy; the answers of the employees indicate that the information about the goals and plans regarding the achievement of the employees is insufficient.

Employee responses stem from managers' knowledge of the company: if the manager of the company does not fully know the structure of the company, the employee certainly does not know it or knows it even worse. This means that employees in the company do not know each other or know each other, but do not know what they are doing and what they are responsible for. This fact points to information gaps in terms of structure, responsibilities and functions. Managers 'knowledge of resources (3.5 points of 5) and employees' answers (2 points of 5) indicate that the company does not have a complete understanding of them. It seems interesting that the knowledge of tasks related to the achievement of low-rated goals (managers: 3.5 points and employees: 2 points) also shows that employees do not know whether and to what extent their work helps to achieve short-term or long-term goals. According to the authors, the arrangement of this aspect in the company should come first, because it would ensure the understanding of the interrelationships and dependencies of the company's activities and the work of employees, as well as show the positive effects of communication. It is possible that other aspects that have been underestimated in the past would be treated differently. Neither managers nor employees are fully confident that they are performing their work to a high standard (4.6 and 4.2 respectively). All these facts point towards great potential for work aimed at preparing the company before starting the process of change and introducing a new model: proper strategies should be implemented to ensure that developmental objectives were considered and included when devising action plans. A review of the key elements of successful activities is required to help capitalize on the strengths of workplace processes and practices. And the leadership staff should spend more time and energy in assisting other employees.

The research results allowed the authors to create a scheme of mutual regularities that could be useful for company managers in implementing changes in the company (see Fig. 5).

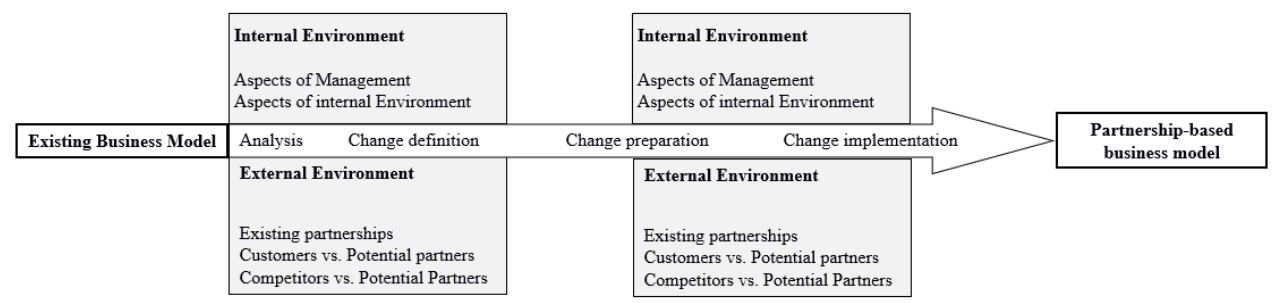

Fig. 5. Transformation process by reinventing of existing business model and implementing a partnership-based business model

With this scheme, the authors want to show what aspects need to be taken into account and analyzed in order to prepare and implement desired changes, in addition, after this analysis the work of defining the necessary changes must be done. After that the above aspects (especially the company's internal environment and management) must be prepared and only then can they be realized in order to transform the business model itself. Aspects such as the company's management and internal processes, functional environment and internal communication flow, employee satisfaction and loyalty, as well as understanding of what is happening are the most important in this process. The environment of customers and competitors is also subject to change, so the authors included them in this analysis process, because in this way it is possible to prepare for change comprehensively and identify additional synergy effects, which could further improve the company's partnership model. 


\section{Conclusions}

A partnership affects the company's operating potential and expands opportunities in the external environment: a new or reinvented business model creates new business strategies in the market, which favour the emergence of advantages over competitors and market the company.

Changes in the external environment affect the company's internal environment and promote new changes in it. A company needs to take full advantage of strengths or successes that occur when work objectives are met or exceeded. A review of the key elements of successful activities is required to help capitalize on the strengths of workplace processes and practices. It also requires that managers at every level are available to their staff and ensure that no information is missed and no misunderstandings occur.

The Management of change, respectively, the Management approach includes a detailed study of the company's internal environment. Considering the fact that employees have a significant impact on how the organization is perceived and help to build and maintain the organization's image, these factors have to be included in change communication, involvement in the processes and motivation to work creatively.

The company's ability to respond to changes in the company's internal and external environments depends on the company's competitiveness and advantages in the operating markets, as well as the quality of the model implementation result. Both internal and external perceptions of organization readiness and willingness are important.

If a company is going to create a business model based on the establishment and provision of strategic partnerships in the long run, company managers should show great interest and full understanding of the importance of partnerships in the context of company's operations. It is important for the company's management to have the skills to apply the acquired knowledge in practice, adapt to new situations, care for quality and manage information.

\section{References}

1. Martinsone, K., Pipere, A., Kamerāde, (2016). Pètniecība. Teorija un prakse (Research. Theory and praxis). Rīga.

2. Ketchen Jr., D.J., Craighead, Ch.W. (2020). Research at the Intersection of Entrepreneurship, Supply Chain Management, and Strategic Management: Opportunities Highlighted by COVID-19. Journal of Management, 46(8), 1330-1341.

3. Nielsen, K., Fredslund, H., Christensen, K.B., Albertsen, K. (2006). Success or failure? Interpreting and understanding the impact of interventions in four similar worksites. Work \& Stress, 20, Art. No. 272287.

4. Vanags, A. (2019). Partnerības stratēg̣ijas modelis mazo un vidējo uzņēmumu konkurētspējas paaugstināšanai. Promocijas darbs, 72-74.

5. Bertels, H.M., Koen, P.A., Elsum, I. (2015). Business Models Outside the Core. Lessons Learned from Success and Future. Research-Technology Management, 58(2), 20-29.

6. Fleisher, C.S., Bensoussan, B.E. (2003). Strategic and Competitive Analysis. Methods and Techniques for Analyzing Business Competition. Pearson Education Ltd., New Jersey.

7. Dale, B. G. (2003). Managing Quality. Blackwell Publishing Ltd.

8. Dobrosotskij, V., Zankovskii, A. (2020). Psychological aspects of effective strategic partnership management. Upravlenie, 8(1), 114-123 
9. Castaner, X., Oliveira, N. (2020). Collaboration, Coordination, and Cooperation Among Organizations: Establishing the Distinctive Meanings of These Terms Through a Systematic Literature Review. Journal of Management, 46(6), 965-1001.

10. Ates, N.Y., Tarakci, M., Porck, J.P., Van Knippenberg, D., Groenen, P.J.F. (2018). The Dark Side of Visionary Leadership in Strategy Implementation: Strategic Alignment, Strategic Consensus, and Commitment. Journal of Management, 46(5), 637-665.

11. Park, S., Grosser, T.J., Roebuck, A.A., Mathieu, J.E. (2020). Understanding Work Teams from a Network Perspective: A Review and Future Research Directions. Journal of Management, 46(6), 1002-1028.

12. Sonnentag, S., Eck, K., Fritz, Ch., Kühnel, J. (2019). Morning Reattachment to Work and Work Engagement During the Day: A Look at Day-Level Mediators. Journal of Management, 46(8), 1408-1435.

13. Hechanova, R.M., Cementina-Olpoc, R. (2013). Transformational leadership, change management, and commitment to change: a comparison of academic and business. organizations. Asia-Pacific Education Researcher, 22(1), 11-19.

14. Kuipers, B.S., Higgs, M., Kickert, W., Tummers, L., Grandia, J., Voet, J.V.D. (2014). The management of change in public organizations: a literature review. Public Administration, 92(1), 1-20.

15. Raineri, A.B. (2011). Change management practices: impact on perceived change results. Journal of Business Research, 64(3), 266-272.

16. Greenberg, J., Baron, R.A. (2014). Behavior in organizations. Harlow, UK: Pearson Education Limited.

17. Weller, I., Süß, J., Evanschitzky, H., Von Wangenheim, F. (2019). Transformational Leadership, High-Performance Work System Consensus, and Customer Satisfaction. Journal of Management, 46(8), 1469-1497.

18. DesJardine, M., Bansal, P., Yang, Y. (2017). Bouncing Back: Building Resilience Through Social and Environmental Practices in the Context of the 2008 Global Financial Crisis. Journal of Management, 45(4), 1434-1460.

19. Adizes, I., K. (2004). Managing Corporate Lifecycles. Adizes Instutute Publishing.

20. Lalhunthara. (2019). Factors Inducing Entrepreneurship: A Study of MSMEs in Aizawl District, Mizoram, SEDME (Small Enterprises Development, Management \& Extension Journal), 46(1) 8-17.

21. Tasnim, N. B. AbuTahoun, Nasreen, K. (2019). The Management Role in Promoting Individual Readiness for Change. In International Conference on Management and Information Systems (pp. 217-222).

22. Tatpuje, D.U., Ganbote, A. (2019). Effectiveness of Online Tools for First Generation Business Start-ups Sustainability in Satara. SEDME (Small Enterprises Development, Management \& Extension Journal), 46(1), 18-23.

23. Foote, J., Midgley, Ahuriri-Driscoll, A., Hepi, M., Earl-Goulet, J. (2017). Systemic evaluation of community environmental management programmes. European Journal of Operational Research, European Journal of Operational Research, 288, 207-224. 